\title{
CONSIDERING THE LINKAGE BETWEEN THE THEORY OF TRUST AND CLASSICAL RURAL SOCIOLOGY'S CONCEPTS
}

Ákos Bodor, Zoltán Grünhut, Réka Horeczki ${ }^{1}$

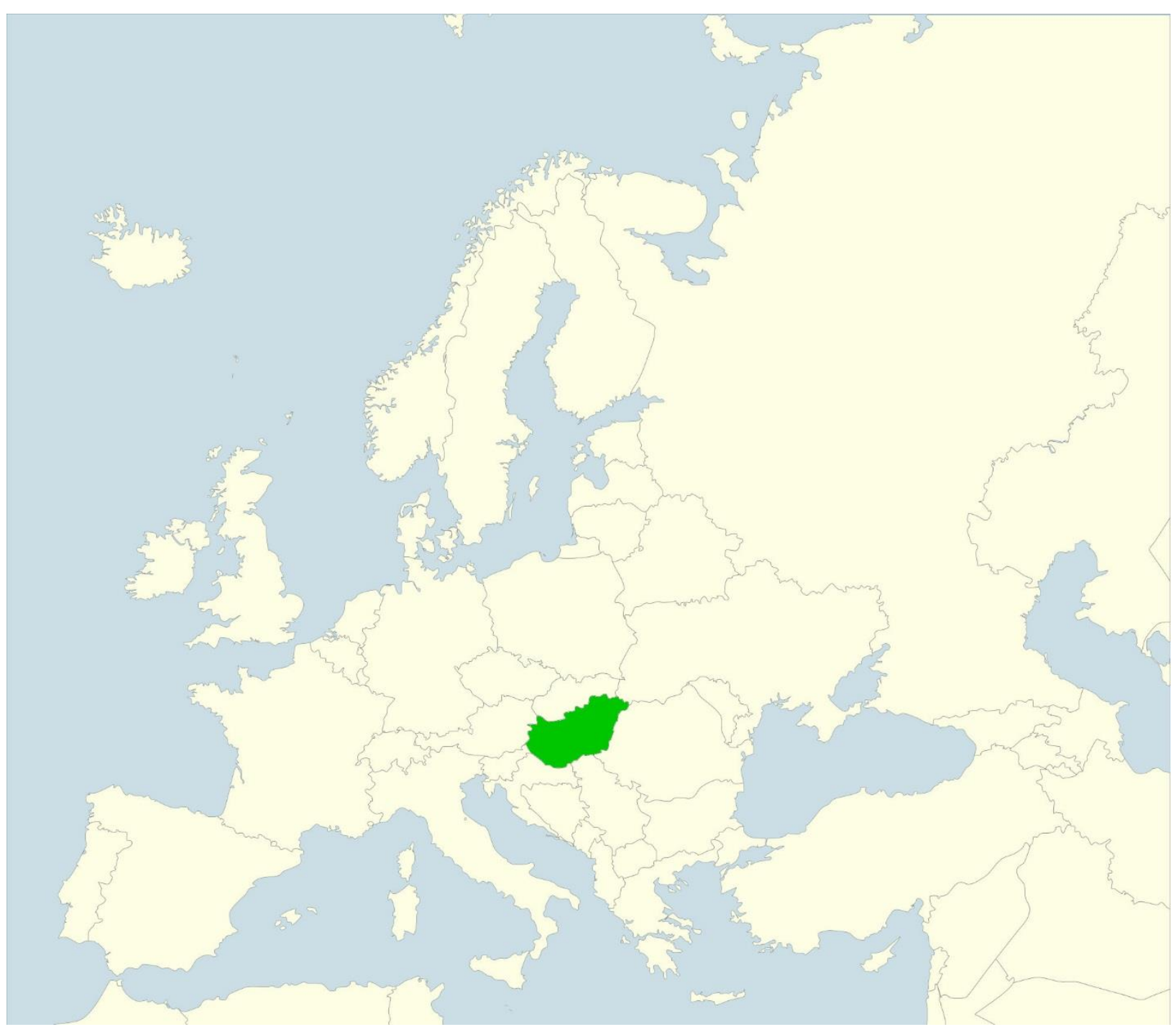

1 Ákos Bodor; bodor@rkk.hu - research fellow, Zoltán Grünhut; grunhut@rkk.hu - research fellow, Réka Horeczki; horeczki@rkk.hu - junior research fellow, Centre for Regional Studies of Hungarian Academy of Sciences, Transdanubian Research Institute. Papnövelde u. 22, 7621 Pécs, Hungary 
Abstract: The paper presents a multi-theoretical argument by linking the mid-range concepts of risk and trust to some core, classical approaches of rural sociology. The main assumption is that risk and trust, two essential features of social interactions in late modernity are influenced by the rural and urban forms of coexistence. Based on the typological grand theories of early rural sociology, countryside-like milieu reduces risks, and by this, supports the individual abilities of showing trust. The paper analyzes this assumption on European countries' data through a quantitative empirical inquiry. The findings do not strengthen the basic hypothesis which conclusion suggests that the classical typological approach of rural sociology should be seen through a critical lens - just as the new theoretical interpretations from the field recommend it.

Keywords: Trust, Risk, Classical Rural Sociology, Typological Approach, European Social Survey

Absztrakt: A tanulmány a bizalom és a kockázat elméleti megközelítéseiből levonható legfontosabb következtetéseket veti össze a klasszikus vidékszociológiai gondolkodók vonatkozó megállapításaival. Ezek alapján kiinduló feltételezésünk, hogy a bizalmat és a kockázatot, mint a társadalmi interakciók alapvető meghatározóit, befolyásolja a vidéki és a városi életfeltételekben a késő modernitás korában is meglévő különbözőség. A vidékszociológia korai átfogó elméletei a vidéki miliőt olyan kiszámítható és biztonságos lakóhelyként mutatják be, amely csökkenti az egyén számára a kockázati helyzetek felmerülését, ezzel növelve a bizalom kialakulásának esélyét. A tanulmányban ezt kíséreljük meg igazolni egy európai országokat átívelő adatbázis empirikus elemzésével. Eredményeink alapján nem lehet egyértelmúen azt a következtetést levonni, hogy a klasszikus vidék szociológia által képviselt vidék-város kettősség létezése kritikai észrevételek nélkül érvényes lenne ma is - ahogyan arra a kortárs vidékszociológiai paradigma képviselői szintén felhívják a figyelmet.

Kulcsszavak: Bizalom, Kockázat, Klasszikus vidékszociológia, Tipológiai megközelítés, European Social Survey

\section{Introduction}

Two mid-range theories that have attracted much scholarly interest in the last decades, particularly in the field of philosophy, sociology, social-psychology, political science and economics, are the interrelating concepts of risk and trust (Sztompka 1999, Zinn 2008). The basic argument dwells on the assumption that in our rapidly changing world, interactions are pervaded with different kind of risks, and to cope with these contingencies, people need to show trust towards each other and also towards more abstract entities. Uncertainties are here to stay; it is not possible to avoid them. People need to perceive and understand risks, and by making choices and decisions to act (or to remain passive) in these contingent circumstances, they rely on their trusting (or distrusting) abilities. Accordingly, trust is a crucial facilitator of interactions, and in a more general sense, it supports social integration and morality.

While this paper accepts this basic argument, it is interested in how these midrange concepts are possibly relating to a more comprehensive social theory which offers explanatory inputs on the emergence (or construction) of risks as well as on the foundation of trust. This aim for a multi-theoretical extension supported the idea to link the concepts of risk and trust to some classic grand theories applied in the field of rural sociology as core - although heavily debated but still respected - arguments. The typological framework of Ferdinand Tönnies about Gemeinschaft (pre-industrial, pre-capitalist, smaller, rather rural communities) and Gesellschaft (industrial, capitalist, urbanized societies) as ideal types of milieus in the social realm is - 
without doubt - a grand theory that describes in a comprehensive way opposing features of social interactions in two different forms of coexistence. Through synthesizations (with the works of Max Weber, Emile Durkheim and Georg Simmel) and by added conceptual developments (from Louis Wirth, Robert Redfield and Howard Newby), this typological approach was influencing theorization of rural sociology for decades. The present paper aims to shed light on how these concepts define the features of Gemeinschaft- and Gesellschaft-like milieus from the point of view of linkages to the theories of risk and trust. To put it shortly and simply: in the ideal rural community stability, calculability, predictability and durability prevails; in the overly homogenous milieu, social statuses and positions are cemented; progression is slow and foreseeable; enduring social bonds and emotional identification support integration and cohesion; sentimental attachments ground the feeling of connectedness both with other members and with the locality; instead of rational calculations, respected traditions and conventions as patterns drive individual deeds; while collective actions are also facilitated by shared norms and responsibilities. Consequently, these early theories of rural sociology suggest that uncertainties and risks are less pervaded in Gemeinschaft-like milieus so people of these communities do not need to challenge their trusting abilities so frequently, which stability and predictability make easier for them to show trust.

In the following, the paper analyzes this simple assumption. The structure is divided into three parts. The first one is a theoretical introduction which presents the elaborated argument, starting with the interrelating concepts of risk and trust, and then proposing an overview on the main theories of early rural sociology from the aspect of linkages to risk and trust. This chapter is followed by an empirical secondary inquiry based on data obtained from the European Social Survey. The quantitative investigation aims to answer the aforementioned assumption if the rural milieu really supports individuals' trusting abilities across Europe. Finally, the paper draws up some concluding remarks.

\section{Theoretical Background}

\subsection{Late Modernity: risk and trust}

Our contemporary world is considered as the age of late modernity by some thinkers, among them most notably Beck et al. (1994), Giddens (1990, 1991), and Lash (1999). Beside other aspects, one of the key features of this period is the pervasiveness of different kinds of uncertainties. To cope with these challenges is a fundamental task for individuals to take part in social interactions. There are certain processes that generate and continuously regenerate these contingencies of our times (Zinn 2008). First of all, the world we are living in is shaped and reshaped by purposeful human efforts; both in a macro and in a micro sense history, politics, societies and cultures are designed and redesigned by individual and collective actions. Fate-dependency is fading away rapidly, while agency is spreading; people are eager to construct, deconstruct and reconstruct their identities (in an autopoietic manner through narrative discourses and performative acts), their way of living and doing things, their perceptions and interpretations on reality, and their paths of life. This active agency is based on the belief that the future is shapeable, nothing is determined or predestined. The growing unpredictability of actorness undermines the traditional social roles, while social statuses become more variable. In all domains of life (consumption, education, labor, leisure, selfidentification, self-expression, etc.) options for choices are booming, inequalities and power dominations are remaining, even increasing, though (Beck 1999).

Beside these processes, there is a tendency of growing interdependencies between actors. Firstly, there are dependencies because of the globalized and extreme division of labor. In our everyday life, the accessibility of services and goods is usually based on complex chains of cooperation and interrelating tasks. Although self-sufficiency is gaining back popularity in different fields of life, yet it has serious limits for a real 'breakthrough'. Secondly, interdependencies are pervaded because of the growing depersonalization, as individuals are more and more dealing with anonymous partners in their routine interactions. Thirdly, not just depersonalization but also technologization is rising which refers to the ever-growing application of automated systems in all spectrums of life. These very sophisticated, even for users just 
partly understood technological systems are dominating our daily practices from communication and financial transactions to online shopping and so many more fields of interactions. Fourthly, the complexity of institutions and organizations responsible for a wide range of functions is an impenetrable global web of agents, procedures and codes of regulations for ordinary people (sometimes even for experts) that shapes individuals' lives and interactions in various forms. All these interdependencies mean uncertainties as the abilities of individuals to control or influence these systems, entities and depersonalized anonymous technological structures are very limited (Sztompka 1999).

To overcome these universalized, globalized and institutionalized risks is a precondition of progression (Beck 1992). Despite these pressuring uncertainties, unpredictable and incalculable future contingencies, individuals need to take actions as risks are irreducible parts of social reality. To cope with these challenges, people have to entrust others. Consequently, trust becomes an incentive of social interactions. Based on this understanding, Piotr Sztompka defines trust simply as 'a bet about the future contingent actions of others' (1999: 25). What does this definition tell us? First of all, that trust relates to a future scenario; the more this contingent outcome is unforeseeable, because of unsatisfying information about it or lacking previous experiences on it, the more one needs to rely on her ability to show trust in advance. Secondly, the above-mentioned definition implies that trust relates to interpersonal interactions. Fukuyama (1995) distinguishes the so-called radiuses of trust; the most inner one refers to family members and close friends addressed as particular trust in the literature, while the most outer radius points to people in general (so to unknown 'others') and it is named as generalized trust. While Sztompka emphasizes that trust dwells in interpersonal relations, it does not mean that all of the involved agents should be individuals or collectives; they can be institutions, organizations, entities, systems, or even objects too, however these impersonal 'subjects' need to be humanly devised and controlled, so there has to be human agency behind their existence. According to Sztompka, faith in non-humanly devised objects cannot be called trust; it should be labeled, instead, as 'hope' and 'confidence', so still positive expectations but under the aegis of fate. Consequently, the third aspect of the definition is that trust relates to actions, it requires more than the passive acceptance of fate.

Theoretically, as it seems, there is a strong interplay between the concept of risk and trust. It is meaningless to talk about risks if all potential uncertainties lead to equally unfavorable future outcomes. When consideration of risks is emerging in a discursive way (irrespective to the number of participants in the discussion; it can be an unexpressed inner monologue as well), it means that at least one better scenario is already recognized compared to the others. And showing trust in advance refers to a positive expectation that from the possible future contingencies this (or one of these) favorable outcome(s) will occur. Therefore, taking risk is a conscious act, at least to some extent. It does not mean that one is always taking into account all the uncertainties, and choosing properly from the identified risks; but in an abstract sense, the subject is aware that her deed has potential risky consequences, as all actions happen in the present and result to something in the future which is usually not predictable in an absolute sense, so it contains uncertainties (Zinn 2008).

To place trust in someone else or in a more abstract entity could refer to different kinds of risks. First of all, there are situations when the other is not aware that somebody entrusts her. In this case, the truster has a prior positive expectation about the trustee's action that it will be beneficial for her even without influencing the trustee anyhow. Secondly, an individual could entrust the other through an exact interaction in which both parties take part. In this case, one's action of showing trust is strongly interrelating with the other's deed, as if the latter turns to be untrustworthy, then the one not just evaluated the risks wrongly, but at the same time she could not influence the other by her expressed positive commitment. Therefore, this is a closer relation between the truster and the trustee with more sensitive consequences. These two sources of positive expectations behind showing trust trace back to rational evaluations about the other(s) and her (their) potential future actions (Coleman 1990, Hardin 2002). Yet, beside this objective pre-justification of entrusting somebody else or a more abstract entity, there is a rather subjective aspect too which is based on psychological, emotional impulses and previously experienced sensitive impacts (Barbalet 1996, Erikson 1987). According to this 
argument, an individual could entrust the other through an exact interaction not just with the aim of expecting favorable outcomes, but also to experience reciprocity in showing trust. If the trustee becomes untrustworthy in a situation like this, then for the truster, not necessarily the unfavorable outcome of the other's action is the most painful but the failed expectation about mutuality. Consequently, it is important to differentiate the rational and emotional $/ \mathrm{moral}$ grounds of showing trust - although in individual praxes both have to have a role -, and to identify which one of the two is dominating in a sense of cultural pattern at the social level (Uslaner 2002).

All that said, it is still a question why is it so important to establish trustful social interactions? Sztompka (1997) distinguishes the functions of trust according to micro (individual) and macro (collective) level impacts. His approach is describable in short by the following pairs of opposites:

1) trust stimulates and mobilizes human agencies such as creativity, innovativeness, lack of inhibitions, risk-taking attitudes and entrepreneurship, while distrust hinders all these by making the individual to follow routines, to accept conformism and subordination, and to be passive;

2) trust strengthens community spirit, collective thinking, willingness to participate and cooperate, it increases the number of interactions and their intimacy, and it broadens network relations, while distrust undermines all these, thus giving rise to isolation, atomization, and collective irresponsibility;

3) trust supports tolerance, acceptance, openness, frankness, willingness to learn, while distrust leads to isolation, defensive attitudes, exclusion, stereotypes, preconceptions and xenophobia;

4) finally, trust fosters individuals' belonging to their community, their identity, it facilitates solidarity, volunteering, and readiness to reciprocate, while distrust makes people rootless, undermines the preference of public good and participation in promoting common goals.

Accordingly, if we accept that in late modernity, uncertainties and risks are pervaded and need to be overcome by establishing trustful social interactions, then trust is a key factor in deepening social integration, increasing moral standards, and generally to facilitate progression and democratization. This argument proposes the question if there are milieus in the social realm which are somehow decreasing risks and uncertainties, and by this, directly or indirectly contributing to the individual abilities of showing trust. This problematization drove our attention to some main concepts of rural sociology.

\subsection{Classical Approaches of Rural Sociology}

In the following chapter, the paper aims to give a brief introduction to some of the main concepts of rural sociology, from the perspective of how these early theories are reflecting to the interrelation between risks and trust. To identify this theoretical linkage, it is important to focus on the idealized differentiation between rural and urban social coexistences. Although this approach is using an abstract conceptual framework to describe the rural and urban milieus, which is hard to adapt properly to the features of reality, yet this interpretation of representing the two realms as idealized opposites is still a respected and applied theoretical understanding of rural sociology.

Ferdinand Tönnies published Gemeinschaft und Gesellschaft (translated as Community and Society) in 1887 (1963), in the age of industrial urbanism. The main argument of the book contrasts features of social interactions and social coexistence dominate in extended families and rural villages, i.e., in small communities (Gemeinschaft, pre-industrial societies) with characteristics of industrialized and urbanized, capitalist settlements and cities (Gesellschaft, industrial societies). Tönnies admits that between these two extremes, all real volition and deeds take place. However, he underlines that most volition and action resemble or are inclined toward one of the opposites. Therefore, he applies Gemeinschaft and Gesellschaft as standards represent only idealized types, yet he claims that by this typological approach, it is easier to 
recognize and describe features of social interactions and social coexistence. Tönnies openly takes a normative perspective in his book insofar as he provides a critique of the impact of industrialization upon social relations. For him, this age of modernization means that people are disrupted from their original and traditional milieu of small communities by moving to the anonymity of the cities where large-scale, impersonal, calculative and quickly changing, instable social relations dominate their interactions. In the Gesellschaft-like milieu people shift from the associative relationships to the contractual one; they base their actions not on bonds of belonging, but rather on rational calculations and choices. All these impacts lead to a more alienated, more atomized and less rigidly structured, sort of 'fluid' and contingent society which turns its back to traditional beliefs and organic norms while it is facing towards the competitiveness of capitalist business and rational science.

In contrast to these tendencies, for Tönnies the pre-industrial, Gemeinschaft-like, small, rural communities are rather homogenous social entities. People of this milieu generally know each other personally well; social roles are quite stable, hardly changing positions which make interactions more predictable. Although there are hierarchical differences and stratifications in these communities that generate inequalities in social statuses, yet, at the same time, there is a sense of bonding togetherness because of the intensity and intimacy of close-knit relationships, the shared traditional understanding on reality and due to the sentimental attachments. Based on this connectedness, people are tempted to show solidarity for each other as well as willingness to take collective actions and responsibilities. Tönnies stresses that Gemeinschaft-like communities are less individualized and more cohesive ones; there is a stronger emotional identification among the members as traditions, well-recognized moral custodians, and bonds to the family, to the neighbors, to the soil and to a particular locality and territoriality make them rather integrated. Accordingly, instead of rationally calculating and justifying their actions, members of these communities have based their deeds on patterns of respected traditions, and enduring conventions and norms while they are more engaged emotionally to each other as well. In Gemeinschaft-like milieu tasks and functions of the members are less diversified, they are more self-supplying, i.e., division of labor is not that much pervaded.

This typological approach of Tönnies - which is still a core conceptual interpretation of rural sociology - was refined by various thinkers later. First of all, it is important to mention Durkheim's (1964) The Division of Labor in Society which has a clear theoretical relation to Tönnies' work. Durkheim was also inspired by the impacts of industrialization and urbanism on social relationships. He identifies the core differentiation between pre-industrial and industrial societies by distinguishing mechanical and organic solidarity which two social phenomena strongly relate to the division of labor. In general, mechanical solidarity is what Tönnies describes as Gemeinschaft-like community spirit. It is based on traditional, from generation to generation transmitted common beliefs and consensuses dwell in the collective consciousness. Economies of communities led by mechanical solidarity are quite primitive, not specialized or diversified as people are rather self-suppliers. Consequently, interdependencies among the members are limited that makes social interactions more predictable. Mechanical solidarity supports communal bonds, kinships and cohesion as it stabilizes social statuses and positions. Compared to Tönnies, Durkheim is not so pessimistic about industrialization and urbanism, as he sees the obstacles of mechanical solidarity, e.g., it cements social hierarchies, provincialism and particularity, i.e., it undermines the evolution of large-scale societal coexistence. Capitalism, the emergence of nationhood, and the development of state-run institutions paved the way for a shift from mechanical to organic solidarity, especially by the ever-growing division and specialization of labor. Although, Durkheim recognizes that these trends lead to alienation, atomization and to a drastic weakening of individual attachment to the collective entity which all could increase deviances, yet he does not suggest that mechanical solidarity-driven communities are normatively better. Especially not due to two reasons: firstly, because organic solidarity contributes to the pervasiveness of rationality which is an important shift to dismantle bounding traditions and constraints; and secondly, since specialization and interdependencies are creating macro, i.e., social level associative mechanisms. This is why Durkheim emphasizes the importance of collective consciousness that could help the ones to cope with the negative effects of individualization, and to deal with the uncertainties and contingencies of social 
interactions. Thus, Durkheim agrees with Tönnies that cohesion is a crucial aspect of social coexistence, yet he rather prefers to identify and push for the opportunities of integration in modern, industrial societies than to feel nostalgia for primitive, pre-industrial communities.

From the early thinkers of (rural) sociology, it is also crucial to mention Max Weber who contributed to the field by two major historical conceptualizations. From a more general perspective by theorizing the emergence of rationality, and particularly by pointing out how this social, political and economic process happened in the German rural context (Weber 1930, 1970). This paper focuses more on the latter one. The core shift that both supported the emergence of urbanism, industrialization, rationality and bureaucratic legitimacy, while at the same time challenged rural coexistence, agriculture-based economy, traditional power and conventional social relations - as Weber stresses - is capitalism. Although he agrees with Tönnies that this shift puts major burdens on the shoulders of both individuals and societies as both find it difficult to re-create settled orders and praxes in these new circumstances, yet Weber - just as Durkheim - is not pessimistic about capitalist modernization or nostalgic about traditional social coexistence. He clearly underlines the limits of aristocratically structured and stratified rural communities where statuses and positions are not outcomes of achievements but of birthrights. For Weber, it is inevitable that by moving from traditional to rational legitimacy, the rural milieu arranged by hierarchy has to be challenged and changed. Peasants are leaving their villages and agriculture and they are soaked up by the rapidly growing cities and industries which reform opens up new uncertainties in the social realm, facilitates heterogeneity, fosters differentiations in occupations, triggers individualization, weakens bonds and kinships, and ties the people more to the legitimate power and to an imaginary abstract society than to the traditional leadership and to the well-known small community and its conventions (Weber 1970).

Louis Wirth as a representative of the Chicago School of Urban Sociology was a large proponent of urbanism and urban life. In his work, entitled Urbanism as a Way of Life published in 1938, he suggests that urban life - besides its 'pathologic' manifestations - facilitates a higher degree of liberty, diversity and tolerance than rural life. He lists three factors crucial to understand social behavior: settlement size, the degree of heterogeneity and population density. According to Wirth, large population leads to specialized division of labor and a growing number of interpersonal relations. Cities, with their large number of inhabitants, do not contribute to the development of kinship relations characteristic of rural societies; interpersonal relations are more heterogeneous and involve weaker ties. Social interactions among city dwellers are fleeting, partial and generally purposive; motivated, for instance, by a need to access services related to the exigencies of urban life.

The essay of Robert Redfield exploring four communities in Mexico echoes the ideas of Wirth. As pointed out in one of his studies published in 1941 (The Folk Culture of Yukatan), the smaller and more isolated a community is, the greater the degree of its homogeneity. Redfield describes the ideal Gemeinschaft type, which, in addition to the aforementioned specifics, relies on a minimal division of labor - stemming from gender differences - and a common ownership of the tools of production. He depicts the more tranquil and predictable lifestyle associated with rural societies less exposed to external impulses which permits individuals to live a more slowpaced, transparent and risk-free existence.

Georg Simmel (1971) describes the distinguishing characteristics of the urban way of life. He presents the everyday life of metropolitan citizens through the example of early $20^{\text {th }}$ century Berlin. He believes that in stark contrast with rural environments, life in the metropolis exposes residents to an enormous amount of stimuli shaping their decisions and social interactions. While recognizing the role of proximity as an important positive externality for urban economies, he points out its potentially negative impacts on integration. Physical proximity increases social distance between the members of a community since concentration and contrasts tend to exacerbate differences, making the heterogeneous lifestyles, habits, mentalities and residential environment of people of various social strata strikingly manifest.

One of the leading figures in Anglo-Saxon rural sociology, Howard Newby analyzed the capitalist transformation of agriculture from the perspective of the restructuring of social 
classes. His theories propose explanations about the changing perceptions of the countryside triggered by the urban and national division of labor. Agricultural workers - people living in the countryside -, according to Newby, are more attached to their traditional values and creeds due to their strong community ties than metropolitan residents. This, as Newby demonstrates, explains the easy identification of farmers' goals: since their Gemeinschaft exhibits a stable harmony, a high degree of cooperation which is viewed as a source of shared pleasure: "Once the correct team spirit is inculcated... then the whole system will run reasonably smoothly" (Newby et al. 1978: 175).

To summarize briefly the multi-theoretical argument of this paper, at first, it is important to note that based on the classical conceptualizations of rural sociology, a coherent narrative is identifiable which stresses that uncertainties are less pervaded in rural milieus, i.e., social relations, statuses, shared traditions and individual agency in these small communities are more predictable, therefore engagement in interactions is less risky. This constellation does not challenge so much individual abilities of showing trust, or to put it in another way: trusting others could be easier as negative experiences such as breaching one's belief in the reliability, truth, or ability of the other is not so common.

Notwithstanding, it is crucial to note that already among the thinkers cited as theorists of classical rural sociology, there is a debate that the ideal type of Gemeinschaft-like milieu could be a tied and bonding community with negative impacts like bounding norms and conventions, cemented hierarchies, constrained actorness and unprogressive structures which critical remarks, to some extent, resonate with certain findings of the literature of trust suggest that in closed and ghettoized collective entities particular trust could utterly overshadow general trust (Banfield 1958, Gambetta 1988). This latter is an unfavorable human praxis since it, though, facilitates kinship relations and familiarity but at the same time it undermines extended, social level integration and morality.

The paper assumes that rural milieu, by decreasing the pervasiveness of uncertainties, contributes to the subjects' trusting abilities towards unknown others, i.e., in respect to general trust (too).

\section{An Empirical Analysis of the Relationship between Trust and Place of Residence}

\subsection{Previous Studies}

In light of the theoretical reasoning presented above and by using empirical data, the current chapter seeks to investigate the assumption according to which people living in the countryside are generally more trusting than people living in urban areas. Initially, the paper claimed that predictable interactions and a permanently low level of risks associated with everyday life were positively related to individuals' trusting abilities, while the next chapter, by drawing on the works of the most prominent authors of classical rural sociology, highlighted that living conditions with a positive influence on trust (a low degree of uncertainty, pre-calculable interactions, a more tranquil environment) were to be found predominantly in rural milieus.

The empirical analysis of this phenomenon is not unprecedented. Putnam (2000) found that trusting behavior was more prevalent outside big cities and ruralites were characterized by a superior level of trust. The study of Debertin and Goetz (2013) examining the relationship between the spatial structure of the United States and social capital, that is, the moral-cultural components crucial to community cohesion, presents similar findings. According to the authors, the level of trust increases in function of the reduction of settlement size, people living in rural communities are the most trusting. Albanese and de Balsio (2014) taking a similar approach, found the role of trust to be less significant in cities. They set up three groups within Europe: North, Center and South. The lowest level of trust was found in Central European cities (Austria, Belgium, France, the Netherlands, Germany and Luxembourg), while the highest was registered in Northern European ones (Denmark, Finland, Ireland, Sweden, United Kingdom). The study of Eriksson et al. (2011) examining the quality of life of Swedish children aged 11-15 compared sense of trust and security among young people living in cities and urban areas. Their findings 
demonstrated that interpersonal trust among young urbanites was lower, which also diminished their subjective sense of security. On the contrary, a study conducted in the same vein by Colbert (2013) detects a higher level of social capital and trust among children and their parents living in cities.

\subsection{Data, Methodology and Results}

The current paper uses data from the 7th wave of the European Social Survey (ESS) of 2014/15 conducted in 21 European countries. Since its launch, the ESS questionnaire has contained the same classical question(s) measuring interpersonal trust. Trust, since several decades, has been measured by the evaluation of answers to the following survey question "Generally speaking, would you say that most people can be trusted or that you need to be very careful in dealing with people?" ESS evaluates the answers on the basis of an 11-point scale (0-10) with 0 indicating that "We need to be very careful" and 10 indicating that "Most people can be trusted". ESS also applies a three-item question - including the one presented above for the more complex measurement of trust. The two additional questions are the following: "Do you think that most people would take advantage of you if they got a chance or would they try to be fair?" The responses were assessed by an 11-point-scale where the value 0 means: "Most people would take advantage", while 10 indicates that "They would try to be fair". The third question is: "Would you say that most of the time people try to be helpful or that they are mostly just looking out for themselves?" Zero points on an 11-point scale indicate that "Mostly people are just looking out for themselves", while 10 signifies that "They try to be helpful".

This study applies a more complex tool for measuring trust obtained by Principal Component Analysis $(\mathrm{PCA})^{2}$. Measuring trust on the basis of principal component scores produces the following results for the individual countries (Figure 1).

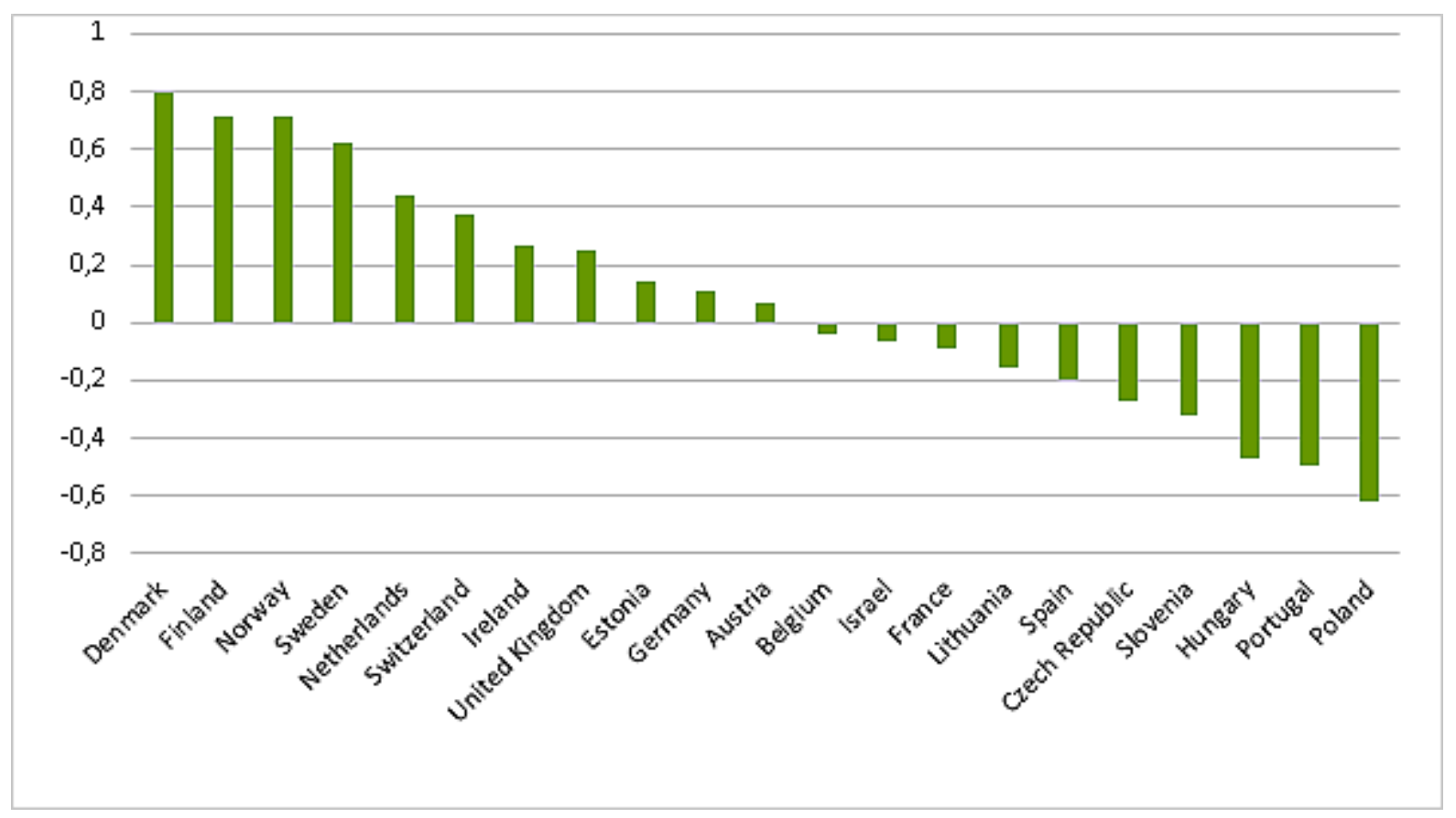

Fig 1. Average trust score by country ( $N=39759$, ESS 7, factor score). Source: Own calculation based on ESS 7 data

As the factor scores do not represent the original scale values (the variables were used in the PCA in a standardized form), so it is crucial to interpret their meanings. Due to the standardization of principal components, the value 0 represents the European mean (calculated for the 21 countries). A negative value can be observed in the case of countries

\footnotetext{
2 The developed principal component preserved the $64 \%$ of the three used variables' original information. The communalities of the variables are between 0.61 and 0.67 . Beyond the PCA the items were tested with Cronbach Alpha too. This result also shows suitable internal consistency (0.72).
} 
where the level of trust is below the European average, while positive values refer to higherthan-average scores. Significant disparities can be detected among European countries in terms of trust (Figure 1). Post-socialist countries and Portugal are among the least trusting societies of the pool. The level of trust observed in Spain, France, Belgium, Israel, and Austria is below the European average. With the exception of Estonia, only Western and North European nations can be found in the group of countries with a superior level of trust.

While the polarization of social capital and more specifically, trust among the above presented countries is a well-researched topic, rural-urban disparities of trust have received considerably less attention from researchers. This is undeniable despite the issue having been subject to theoretical investigations in various scientific disciplines for several decades - as demonstrated by the theoretical review contained in our study. Nonetheless, examples of the empirical validation of hypotheses are still relatively scarce. Obviously, this is due to the absence of data or the limited usability of survey-type data accessible at the subnational level.

The current paper seeks to remedy this problem by omitting NUTS categories as objective databased indicators of the spatial location of respondents' residence, and introducing a variable which contains a subjective typology of dwellings. In ESS and similar large-scale international comparative analyses, respondents' territorial identification - by country - is enabled by NUTS classification. This categorization, however, is of little use when investigating rural-urban disparities. Besides, the database contains no data on the administrative typology of settlements identified as the respondent's place of residence. In the meantime, the questionnaire contains a question that reads: "Which phrase on this card best describes the area where you live?" 1) big city; 2) suburbs or outskirts of a big city; 3) town or a small city; 4) country village; 5 ) farm or home in the countryside." For technical reasons and in order to ensure a sufficient sample size, the first and last two response options were merged. The resulting variable contains three categories of settlements: 1) big city; 2) A town or a small city; 3) A country village/farm. The current study uses this subjective residence typology. The subjective character of the typology is based on respondents' individual perception of their residential environment. Figure 2 illustrates the sample distribution of the three categories.

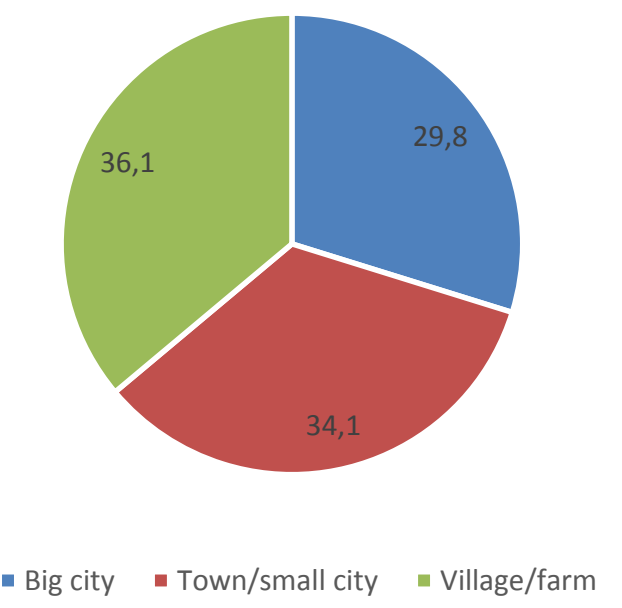

Fig 2. The distribution of settlement categories, by percentage ( $N=40095$, ESS $=7)$. Source: Own calculation based on ESS 7 data

The primary objective of the study is to reveal the assumed differences of trust between urban and rural areas. The review of classical rural sociology literature indicates a causal relationship stemming from the positive impact of Gemeinschaft-like lifestyles on developing and maintaining trust. The coming section of the chapter is going to test this hypothesis. More precisely, the paper tests the data-sense observability of the assumed empirical consequence derived from the above elaborated multi-theory; namely that people living in rural areas, on average, have a higher level of trust. 


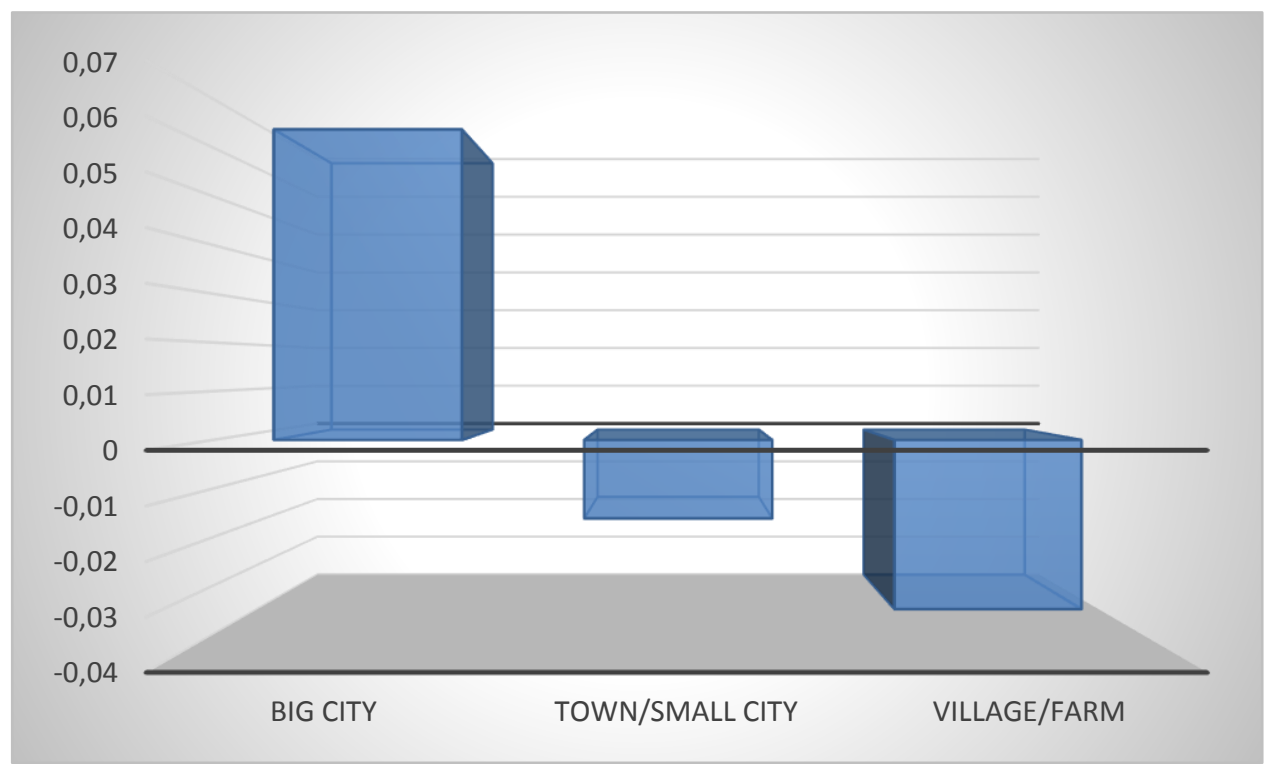

Fig 3. Average trust scores by settlement category ( $N=39673$, ESS7, factor score). Source: Own calculation based on ESS 7 data

Figure 3 presents the average trust scores measured in the three settlement categories on the basis of data taken from the $7^{\text {th }}$ wave of the ESS. It shows significant discrepancies between the level of trust and place of residence in the sample containing data on the 21 countries. The results of the survey, contrary to the assumption, reveal that residents of big cities obtain higher average trust scores than those belonging to the other two settlement categories. The data also highlight that residents of the smallest settlements are the least trusting. Due to this outcome, it is clear that the proposed assumption is not observed on the merged 21country-sample. ${ }^{3}$ It still remains to be tested, however, whether the urban-rural trust divide varies across countries (Figure 4).

Figure 4 presents the specificities of trust in the 21-country-pool in a complex way. Vertical axis shows the level of trust ( 0 is the European average), while the horizontal one lists the countries exactly in the same order just on Figure 1 (so, Figure 1 is incorporated into Figure 4; from left to right, the level of trust is decreasing). The novelty of Figure 4 is that it shows not the average trust scores at national level but according to the three settlement categories related to every country. The blue spot refers to the average trust scores of people living in big cities; red $x$ covers those who are from a town/small city; while green star is applied in the case of village and farm residents. Consequently, related to every country, it is readable on Figure 4 in which settlement category trust on average is higher or lower.

Interpreting the data demonstrated on Figure 4, it is interesting to note that in more trusting societies, so in countries with a higher level of average trust than the European mean value (note: Austria, Belgium and Israel are the closest ones to the average; see it on Figure 1), the discrepancies among settlement categories are less relevant. Or to put it differently, the average trust of big city, town/small city, and village/farm residents is more balanced in those societies that show a higher level of trust at national level.

\footnotetext{
${ }^{3}$ It is important to note here that this examination could not validate/falsify particularly the assumed causal linkage (rural milieu facilitates trust); it just revealed the observable empirical case of average trust scores in the three settlement categories. Due to this, it cannot be said that the assumed causal relationship should be rejected completely.
} 


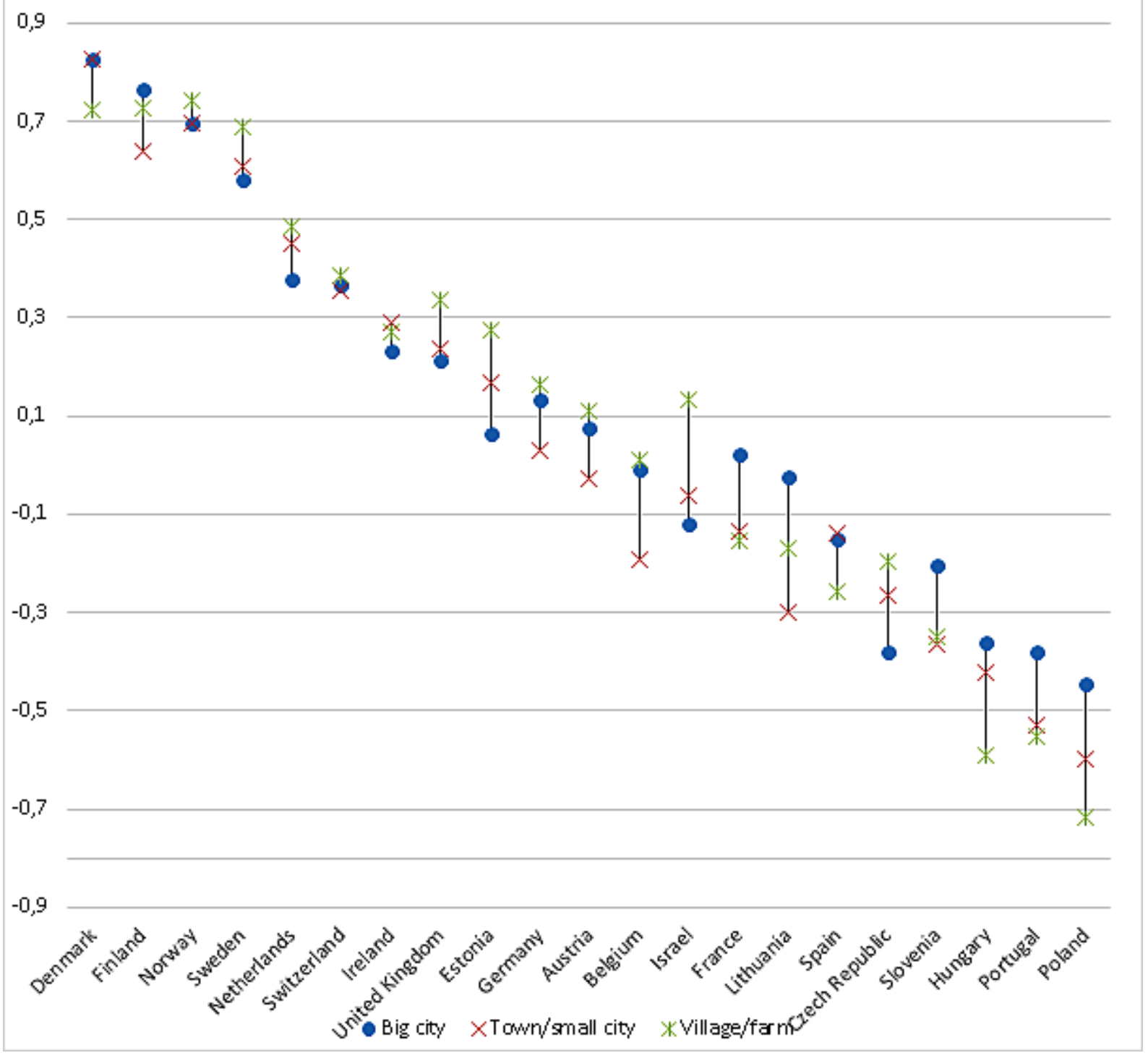

Fig 4. Average trust scores by settlement category and country ( $N=39673$, ESS7, factor score). Source: Own calculation based on ESS 7 data

It is also worth to mention that in countries with an average trust lower than the European mean value big city dwellers are the most trusting ones (except in the case of the Czech Republic), while village/farm residents are usually the least trusting people. At the same time, in those societies that show a higher average trust than the mean value, on the contrary, generally, dwellers of the smallest settlements are more trusting (although, as it was said in the previous paragraph, differences among settlement categories are much smaller related to these countries).

Based on these observations the idea to classify the countries into certain groups in order to reveal more in-depth findings seemed promising. Four groups have been developed: North (Denmark, Finland, Norway, Sweden), West (Netherlands, Switzerland, Ireland, United Kingdom, Germany, Austria, Belgium), South (France, Spain, Portugal), and East (Estonia, Lithuania, Czech Republic, Slovenia, Hungary, Poland) (see Figure 5 bellow).

One country, Israel, was not classified into any of these groups. Yet, it is interesting to devote some thoughts to the Jewish state. At first, it should be mentioned that with respect to the differences of average trust scores among settlement categories, Israel demonstrates a case where people living in villages/farms are much more trusting than their fellows dwelling in big cities or towns/small cities. It is well known that the Jewish state's rural settlements, 
the so-called kibbutzim and moshavim, represent very unique community-forms which, although, have deeply changed during the last decades but still preserve specific features (BenRafael 1997). Originally, these settlements, especially the more strictly organized kibbutzim were pretty much like how Tönnies conceptualized the ideal Gemeinschaft-type milieu. Even more, up until the 1970s, kibbutzim were principally committed to the idea of equality in the broadest possible sense (Gavron 2000), so these communities purposefully aimed to overcome some of those negative tendencies (for instance, social hierarchy, unjust privileges, patriarchal culture, etc.) that were criticized by Durkheim and Weber in the theory of Tönnies. For long, members could not have individual property and wealth; almost everything were collectively possessed and therefore shared from produced goods, through the labor tools and real-estates, even up to particular chattels. Not just community issues but nearly every single decision were democratically debated and adopted through direct participation. Positions were shifted regularly among the members, so everybody could develop different skills and acquire various knowledge and experiences (Ben-Rafael 1995). Hence, social roles often changed, yet statuses were quite fixed and stable (and equal too). This mechanism made, on the one hand, the kibbutzim themselves almost entirely self-supplier while, on the other, it contributed to the realization of Durkheimian mechanic solidarity in practice. Obviously, these principled procedures required and also reproduced a conventional community culture based on respected values and norms and predictable attitudes and behaviors. Bonding kinships, sentimental attachments, enduring and well-recognized moral and ideal-ideological patterns and intimate and intensive social relations institutionalized a close-knit cohesion. Therefore, despite all the reforms have occurred in kibbutzim and moshavim since the 1980s, Israel still demonstrates a unique rural life and quality (Near 1995), something quite similar to the theory that this paper's assumption was based on.

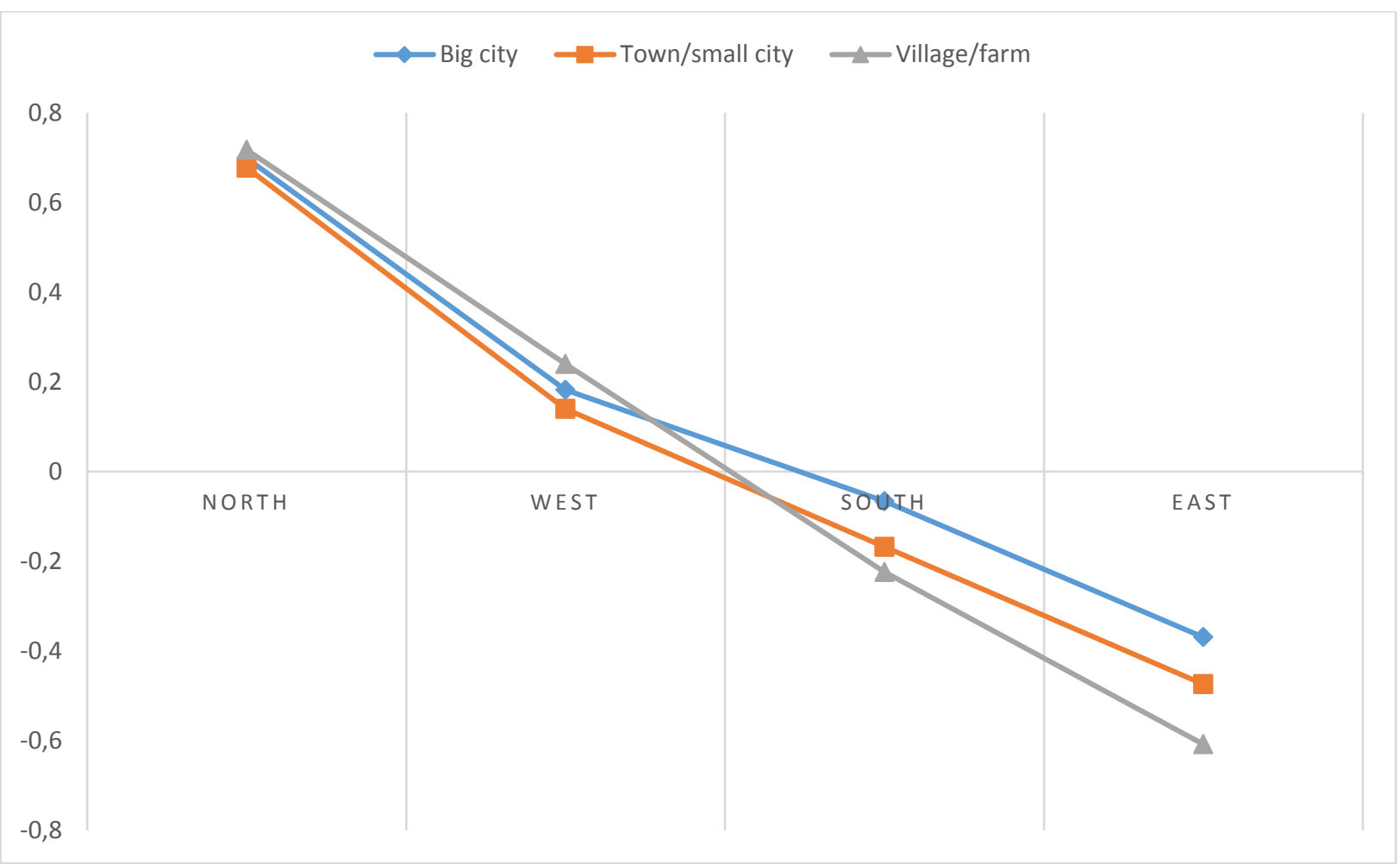

Fig 5. Average trust scores by settlement category and country-groups ( $N=37157)$, ESS7, factor score). Source: Own calculation based on ESS 7 data

Figure 5 displays the average trust scores by settlement categories in the four country-groups. The vertical axis shows the level of trust ( 0 is the European mean value), while on the horizontal axis are the country-groups from right to left the North, West, South and East. As it is clearly demonstrated on Figure 5, the average trust scores of country-groups are decreasing from right to left (i.e., from the North group to the East), while the discrepancies among the settlement categories are increasing. There is also a remarkable shift related to the settlement categories, 
insofar in the North and West group village/farm residents are a bit more trusting than residents of big cities and towns/small cities, while respective to the South and especially to the East group, on the contrary, people living in village/farm are the least trusting. Consequently, we can stress that in a European perspective the proposed assumption did not work, or to say, people from rural milieus are showing less trust (contrary to the presumption) than residents of urban neighborhoods because of the empirical observations related to the Southern countries and particularly to the Eastern, post-socialist 'new democracies'.

\section{Conclusion}

The paper's results did not enable us to present overall conclusive statements about the rural and urban specificities of trust in a European perspective. While the level of trust measured in rural and urban societies was quite heterogeneous in the case of one half of the countries, in the other group no significant disparities were registered.

Consequently, it is impossible to offer a general interpretation of our results within the framework of classical theories of rural sociology, which is in line with the new theoretical postulations and arguments of the field. Privileging the analysis of discursive constructions embodying diverging interests and notions over the examination of objective criteria is a dominant tendency in the contemporary scientific interpretation of social disparities characterizing rural and urban societies. Attempts have been made to question and redefine the concept of 'countryside' according to the ideas and interpretations of middle-class urban consumers, the main users of rural space. Therefore, rural-urban disparities over the past decades have increasingly been interpreted as competing social constructions, with discursive and representational functions gaining relevance in the definition of rurality (Mormont 1990, Ray 1998). According to this new approach, the traditional rural-urban dichotomy is no longer relevant, rendering impossible the geographical identification of the cultural markers of rural life, which latter are but socially constructed and maintained discursive ideas. Consequently, specific types of social disparities can no longer be directly attributed to specific categories of settlements. Applying this approach in the interpretation of our findings leads us to conclude that the demonstrable rural-urban disparities of trust can no longer be explained by the already noted distinctive features of rural and urban societies, but various other determining factors. The validity of early classical theories presented in the introductory chapter is therefore limited and should be approached through a critical lens, notwithstanding that the traditional ideas of rural sociology still dominate the scientific context as well as the lay perceptions and public discourse. Before setting these early concepts aside once and for all through an overly exaggerated critique, it must be noted that classical authors were well aware that the typological approach was suitable only for the description of ideal types which were never present in real life in their pure form. Nonetheless, the marked tendency of constantly diminishing disparities is undeniable.

The focus this paper was limited to the presentation of demonstrable differences of trust since the available data did not permit the detection of more complex causal relations underlying our results. In order to facilitate a better understanding of trust and elaborate theoretically and empirically well-grounded arguments of rural sociology, an in-depth survey of the causal aspects of the research in this direction would be highly useful.

\section{Acknowledgements}

The research of Ákos Bodor has been conducted as part of the National Excellence in Higher Education Program in Hungary (reference number: 20765-3/2018/FEKUTSTRAT). The research of Zoltán Grünhut was supported by the Bolyai Research Scholarship of the Hungarian Academy of Science. The research of Réka Horeczki was part of the project no. 116424 which has been implemented with the support provided from the National Research, Development and Innovation Fund of Hungary, financed under the K_2015 funding scheme. 
[1] Albanese, G. \& Blasio, G. (2014). Who trusts others more? A cross-European study. Empirica 41(4), 803-820. DOI: 10.1007/s10663-013-9238-7.

[2] Banfield, E. (1958). The moral basis of a backward society. New York: New York State University.

[3] Barbalet, J. (1996). Social emotions: confidence, trust and loyalty. International Journal of Sociology and Social Policy 16(9-10), 75-96. DOI: 10.1108/eb013270.

[4] Beck, U. (1992). Risk society: towards a new modernity. London: Sage.

[5] Beck, U. (1999). World risk society. Malden: Polity.

[6] Beck, U., Giddens, A. \& Lash, S. (1994). Reflexive modernization. Cambridge: Polity.

[7] Ben-Rafael, E. (1995). The kibbutz in the 1950s. In Troen, S. I. \& Lucas N., eds., Israel: The First Decade of Independence (pp. 265-278). Albany: SUNY Press.

[8] Ben-Rafael, E. (1997). Crisis and transformation: the kibbutz at century's end. Albany: SUNY Press.

[9] Colbert, J. (2013). Settlement and social capital: strengthening futures for newcomer children and society [RCIS Working Paper No. 2013/5]. Toronto: Ryerson University.

[10] Coleman, J. S. (1990). Foundations of social theory. Cambridge: Harvard University Press.

[11] Debertin, D. L. \& Goetz, S. J. (2013). Social capital formation in rural, urban and suburban communities. [Staff papers in University of Kentucky No. 474]. Lexington: University of Kentucky.

[12] Durkheim, E. (1964) [1894]. The division of labor in society. New York: The Free Press.

[13] Erikson, E. (1987). Childhood and society. London: Collins.

[14] Eriksson, U., Hochwälder, J. \& Sellström, E. (2011). Perceptions of community trust and safety - consequences for children's well-being in rural and urban contexts. Acta Paediatrica 100(10), 1373-1378. DOI: 10.1111/j.1651-2227.2011.02579.x.

[15] Fukuyama, F. (1995). Trust. The social virtues and the creation of prosperity. New York, Free Press.

[16] Gambetta, D. (1988). Mafia: The price of distrust. In Gambetta, D., ed., Trust: making and breaking co-operative relations (pp. 158-175). Oxford, Basil Blackwell.

[17] Gavron, D. (2000). The Kibbutz: awakening from utopia. Lanham: Rowman \& Littlefield.

[18] Giddens, A. (1990). The consequences of modernity. Cambridge: Polity.

[19] Giddens, A. (1991). Modernity and self-identity. Self and society in the late modern age. Cambridge: Polity.

[20] Hardin, R. (2002). Trust and trustworthiness. New York: Russell Sage Foundation.

[21] Lash, S. (1999). Another modernity. A different rationality. Oxford: Blackwell.

[22] Mormont, M. (1987). Rural nature and urban nature. Sociologia Ruralis 27(1), 1-20. DOI: 10.1111/j.1467-9523.1987.tb00314.x.

[23] Near, H. (1995). The crisis in the kibbutz movement. In Troen, S. I. \& Lucas N., eds., Israel: The First Decade of Independence (pp. 243-264). Albany: SUNY Press.

[24] Newby, H., Bell, C., Rose, D. \& Saunders, P. (1978). Property, paternalism and power. Class and control in rural England. London: Hutchinson.

[25] Putnam, R. D. (2000). Bowling alone. The collapse and revival of American community. New York: Simon and Schuster. 
[26] Ray, C. (1998). Culture, intellectual property and territorial rural development. Sociologia Ruralis 38(1), 3-20. DOI: 10.1111/1467-9523.00060.

[27] Redfield, R. (1941). The Folk Culture of Yucatan. Chicago: University of Chicago Press.

[28] Simmel, G. (1971) [1903]. The metropolis and mental life. In Simmel, G. (edited by Levine, D.) On individuality and social forms (pp. 324-339). Chicago: Chicago University Press.

[29] Sztompka, P. (1997). Trust, distrust and two paradoxes of democracy. European Journal of Social Theory 1(1), 19-32. DOI: 10.1177/136843198001001003.

[30] Sztompka, P. (1999). Trust. A sociological theory. Cambridge: Cambridge University Press.

[31] Tönnies, F. (1963) [1867]. Community and society. New York: Harper \& Row.

[32] Uslaner, E. (2002). The moral foundations of trust. Cambridge: Cambridge University Press.

[33] Weber, M. (1930). The Protestant ethic and the spirit of capitalism. New York: Scribner.

[34] Weber, M. (1970) [1904]. Capitalism and rural society in Germany. In Gerth, H. H. \& Mills, C. W., eds., From Max Weber: Essays in Sociology (pp. 363-386). London: Routledge.

[35] Wirth, L. (1938). Urbanism as a way of life. American Journal of Sociology 44(1), 1-24. DOI: $10.1086 / 217913$.

[36] Zinn, J., ed. (2008). Social theories of risk and uncertainty. Oxford: Blackwell. 